\title{
NEW DATA OF POTAMOPHYLAX ROTUNDIPENNIS (BRAUER, 1857) AND THE FIRST RECORD OF STENOPHYLAX PERMISTUS MCLACHLAN, 1895 (TRICHOPTERA: LIMNEPHILIDAE) FROM KOSOVO
}

\section{Halil Ibrahimi ${ }^{1 *}$, Valentina Slavevska-Stamenković ${ }^{2}$, Biljana Rimcheska ${ }^{2}$, Astrit Bilalli ${ }^{3}$ \& Milaim Musliu ${ }^{3}$}

\author{
${ }^{1}$ Department of Biology, Faculty of Mathematics and Natural Sciences, University of Prishtina \\ „Hasan Prishtina”, Mother Theresa street p.n., 10000 Prishtina, Kosovo \\ ${ }^{2}$ Institute of Biology, Faculty of Natural Sciences and Mathematics, Gazi Baba bb, 1000 Skopje, \\ Macedonia \\ ${ }^{3}$ Faculty of Agribusiness, University of Peja „Haxhi Zeka”, UÇK street, 30000 Pejë, \\ Republic of Kosovo
}

Ibrahimi, H., Slavevska-Stamenković,' V., Rimcheska, B., Bilalli, A. \& Musliu, M: New data of Potamophylax rotundipennis (Brauer, 1857) and the first record of Stenophylax permistus McLachlan, 1895 (Trichoptera: Limnephilidae) from Kosovo. Nat. Croat., Vol. 25, No. 2., 259-266, 2016, Zagreb.

In this paper we report two new records of the rare limnephilid species Potamophylax rotundipennis (Brauer, 1857) from the Balkan Peninsula, more precisely from the Republic of Kosovo. The first sampling station is located around the spring area of the only stream inside Blinajë Hunting Reserve in central Kosovo, and the second one in the middle section of the Turuqicë tributary of the Llap River in northern Kosovo. From Blinajë Hunting Reserve we also report Stenophylax permistus McLachlan, 1895 for the first time from the Republic of Kosovo.

Keywords: Potamophylax rotundipennis, Stenophylax permistus, Kosovo, rare species

Ibrahimi, H., Slavevska-Stamenković,' V., Rimcheska, B., Bilalli, A. \& Musliu, M: Novi podaci o vrsti Potamophylax rotundipennis (Brauer, 1857) i prvi nalaz vrste Stenophylax permistus McLachlan, 1895 (Trichoptera: Limnephilidae) s Kosova. Nat. Croat., Vol. 25, No. 2., 259-266, 2016, Zagreb.

U ovom radu su prikazana dva nova nalaza rijetke vrste porodice Limnephilidae, Potamophylax rotundipennis (Brauer, 1857) s Balkanskog poluotoka, točnije iz Republike Kosovo. Prvi lokalitet se nalazi na izvorišnom području jedinog potoka unutar lovnog rezervata Blinajë u središnjem Kosovu, a drugi na srednjem dijelu pritoke rijeke Llap, Turuqicë, na sjeveru Kosova. U Blinaji je također utvrđena po prvi puta na području Kosova vrsta Stenophylax permistus McLachlan, 1895.

Ključne riječi: Potamophylax rotundipennis, Stenophylax permistus, Kosovo, rijetke vrste

\section{INTRODUCTION}

The genus Potamophylax Wallengren, 1891 is a typical example of the caddisflies that originated and have diversified in the European continent (KumAnsKI \& MALICKY, 1999).

\footnotetext{
*Corresponding author: halil.ibrahimi@uni-pr.edu
} 
Out of more than 40 taxa that have been described, only two are distributed outside the European continent (e.g. Kumanski \& Malicky, 1999; Oláh et al., 2013b; OláH \& Kovacs, 2013, 2014). Compared to other regions of Europe such as the Iberian Peninsula, the Apennines and Carpathian mountains, the Balkan Peninsula is definitely one of the main speciation areas with many microendemics and rare species (Olát et al., 2011, 2013b; OláH \& Kovacs, 2013, 2014). Some species of this genus are however frequent habitants of freshwater ecosystems, including lakes (e.g. Lillehammer, 1978; Kiss et al., 2003), in particular parts of Europe while in other parts their distribution is fragmented or inadequately known. Potamophylax rotundipennis is reported from several localities in Northwestern and Central Europe but until recently there has been no record from Southeastern Europe. During 2012 the first record of this species for Kosovo and the Ecoregion 6, Hellenic Western Balkans (according to Illies 1978) was registered (IвRAнімі et al., 2012a).

Stenophylax permistus is a widespread species in Europe, present in almost all ecoregions and mostly associated with hypocrenal, epirhithral and metarhithral zones (GRAF et al., 2008).

The aim of this paper is to contribute further to the knowledge of the distribution patterns of P. rotundipennis in southeastern Europe and especially in Kosovo (Pongrácz, 1923; Radovanović, 1931; Marinković-Gospodnetić, 1975, 1980; MALicky, 1986, 1999; OlÁH, 2010, OlÁH et al., 2013a, 2013b; IвRAHImi \& GASHI, 2008; IвRAHIMi et al., 2012a, 2012b, 2013, 2014a, 2014b, 2015a, 2015b, 2016) including new faunistic records from associated species.

\section{MATERIAL AND METHODS}

\section{Study area}

The material was collected from two localities belonging to the Black Sea watershed in Kosovo (Fig. 1). Both localities belong to zoogeographic region 6, Hellenic Western Balkans according to ILLIEs (1978). The first sampling station (Fig. 2) is located in Turuqicë village in the stream bearing the same name, a right tributary of the Llap River $\left(42^{\circ} 77^{\prime} 09^{\circ} \mathrm{N}, 021^{\circ} 32^{\prime} 62^{\circ} \mathrm{E}, 864 \mathrm{~m}\right.$ above sea level). The stream bed is $3-4$ meters wide. The substrate is dominated by silt, sand, small sized boulders and only rarely medium to large stones. The submerged vegetation and streambank vegetation is relatively well developed. The second sampling station is located in the Blinajë Hunting Reserve, 15 $\mathrm{km}$ on the western side of Lipjan town. There are 33 artificial lakes present inside this area. The sampling site (Fig. 3) is located in the spring of the only stream in the area; it is adjacent to the biggest lake in Blinajë Hunting Reserve, where it discharges about $600 \mathrm{~m}$ after the spring $\left(42.5185^{\circ} \mathrm{N}, 20.9788^{\circ} \mathrm{E}\right.$, and $721 \mathrm{~m}$ above sea level). The substrate is dominated by sand and small to large sized boulders. The stream bed is about 1 meter wide. The streambank vegetation and riparian vegetation are well developed with a large amount of decaying trees and vegetation surrounding the locality.

\section{Sampling methods}

Adult caddisfly specimens were collected with entomological net, handpicking and ultraviolet light traps. The sampling was carried out during 2014. Two types of ultraviolet light trap were used: a) a pyramid UV light trap which operated for about two hours and $b$ ) white pan light trap where the ultraviolet light was placed above a white pan of $60 \mathrm{~cm}$ in diameter, filled $10 \mathrm{~cm}$ with water and a few drops of detergent. This light 
trap was placed on the stream bank and operated from dusk until morning. Collected samples were preserved in $80 \%$ ethanol. The specimens were identified under a stereomicroscope with determination keys from MaLicky $(2004)$ and Kumanski $(1985,1988)$.

Note: Female specimens of the genus Hydropsyche are identified only up to the generic level due to the difficulties in identifying properly species of this genus up to the species level. Female specimens of the genus Tinodes are also identified only up to the generic level for the same reason. Probably the female from station 1 belongs to the species Tinodes janssensi Jacquemart, 1957, which has been previously reported from this area (IвRAнім et al., 2012a). Females of this species are not safely identifiable.

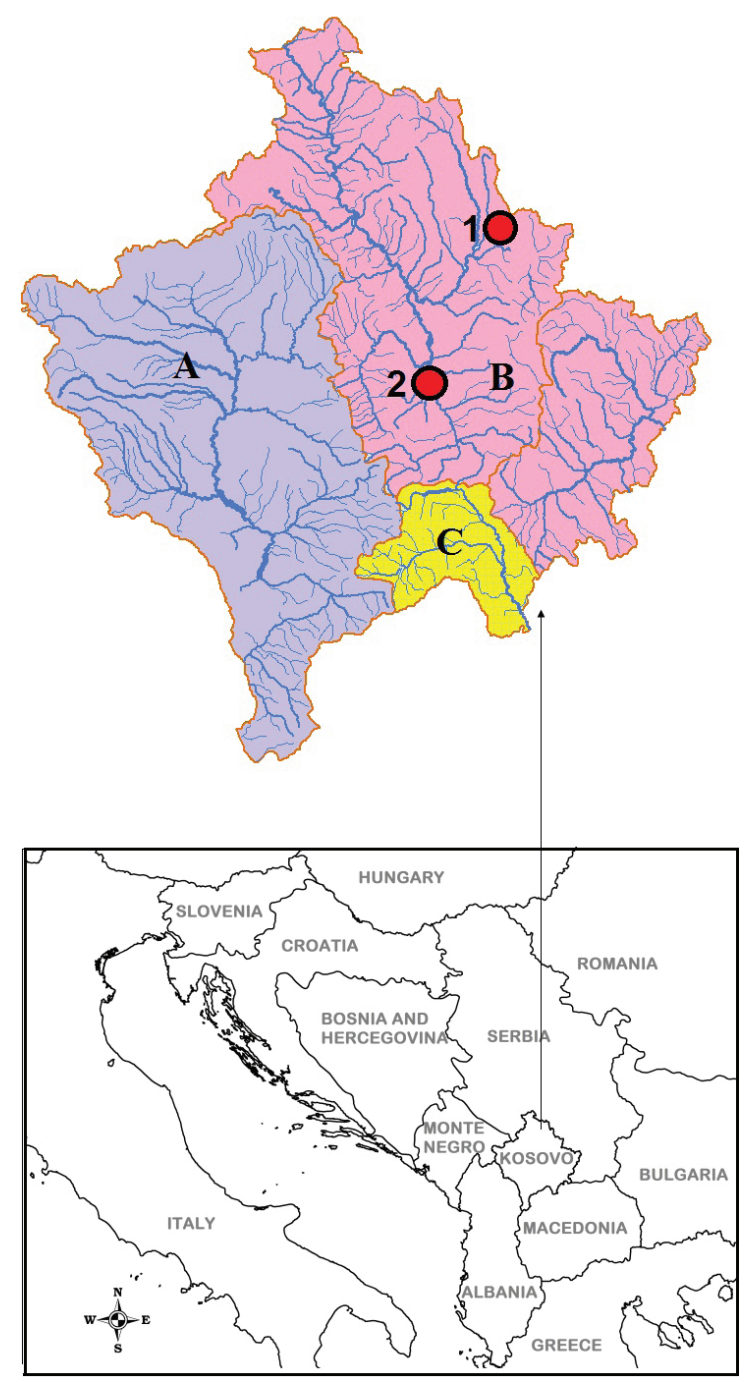

Fig. 1. Sampling stations: 1. Turuqicë, 2. Blinajë; A. Adriatic Sea watershed, B. Black Sea Watershed, C. Aegean Sea Watershed. 


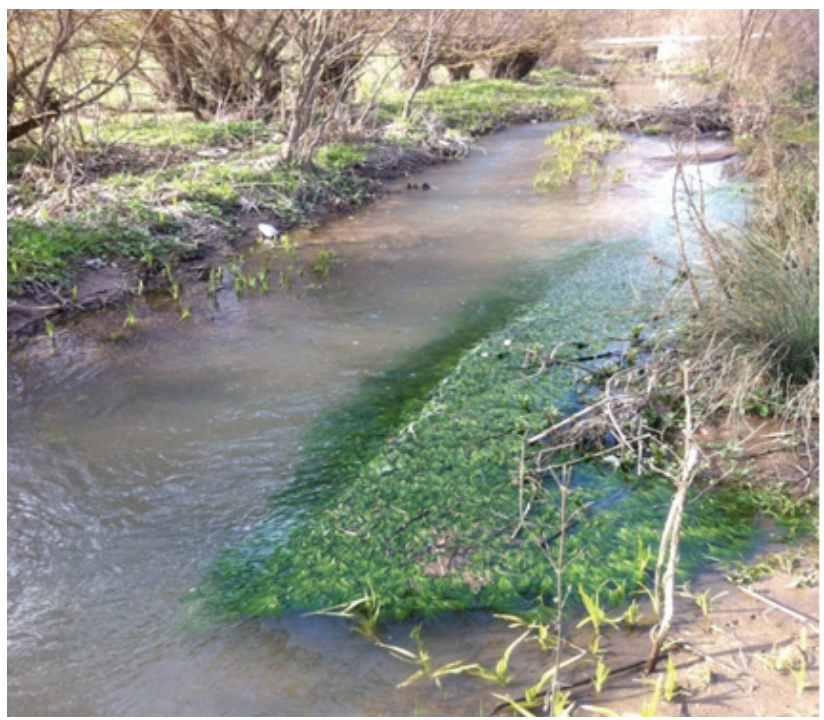

Fig. 2. Station 1 - Turuqicë stream in Turuqicë village.

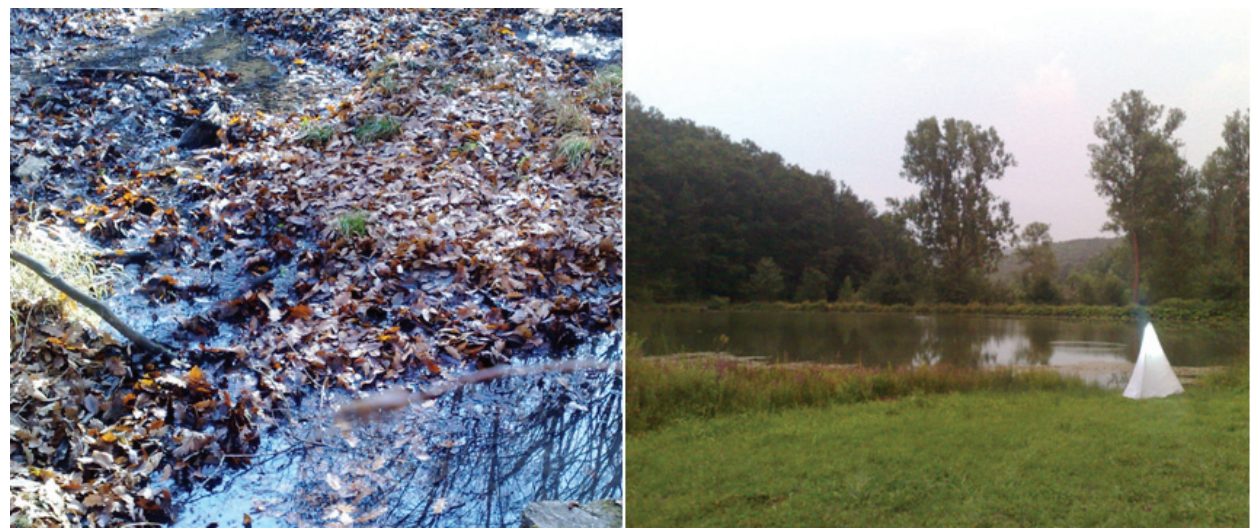

Fig. 3. Station 2 - Blinajë stream discharging into the first lake in Blinajë Hunting Reserve.

Specimens were determined by the first author. The collection is deposited at the Laboratory of Zoology of the Faculty of Natural and Mathematical Sciences, University of Prishtina, Kosovo.

\section{RESULTS}

\section{Material examined:}

\section{Station 1, Turuqicë River:}

12.07.2014 (UV pyramid light trap): Hydropsyche spp., 4 females; Rhyacophila fasciata Hagen, 1859, 3 males. 
15.08.2014 (UV pyramid light trap): Drusus botosaneanui Kumanski, 1968, 1 female, 2 males; Potamophylax rotundipennis 1 female, 1 male.

15.09.2014 (UV white pan light trap): Rhyacophila fasciata 1 female, 3 males; Drusus botosaneanui 4 females, 1 male; Potamophylax rontundipennis 1 male.

19.10.2014 (entomological net): Rhyacophila fasciata 1 male.

20.11.2014: no specimen found.

\section{Station 2, Blinajë stream.}

12.07.2014 (UV pyramid light trap): Hydropsyche spp., 4 females; Tinodes spp. 1 female.

13.08.2014 (UV pyramid light trap): Potamophylax pallidus (Klapalek, 1899), 8 females, 12 males; Potamophylax rotundipennis 1 female, 3 males; Micropterna nycterobia McLachlan, 1875, 5 females.

15.09.2014 (UV white pan light trap): Rhyacophila fasciata 1 female, 1 male; Potamophylax pallidus 4 females, 11 males; Potamophylax rotundipennis 2 females, 7 males; Hydropsyche spp. 3 females.

19.10.2014 (UV pyramid light trap): Micropterna nycterobia 4 males; Potamophylax pallidus 5 females, 2 males; Potamophylax rotundipennis 4 females, 3 males, Stenophylax permistus 2 males.

20.11.2014 (entomological net; handpicking): Potamophylax pallidus 1 female; Mesophylax aspersus (Rambur, 1842) 1 male; Potamophylax rotundipennis 3 males.

\section{DISCUSSION}

In Switzerland and the Netherlands P. rotundipennis has been reported from lowland sandy creeks with lots of dead wood and leaf packages (Higler \& Solem, 1986; Lubini et al., 2012). All localities in which P. rotundipennis occurs in Kosovo are characterized by the surrounding presence of a large amount of fallen leaves, branches, dead wood and decaying trees. Station 1 is an exception but this species has been reported previously, in medium sized rivers as well (WALLACE, 2010). However the conditions of this type of freshwater ecosystems do not seem to be optimal for populations of $P$. rotundipennis. Basically the species can be found from the epirhithral to the epipotamal zone but with a strong preference for the metarhithral and hyporhithral zones (GrAf et al., 2008). In Station 1, but also in two previously reported stations in which $P$. rotundipennis occurs in Kosovo (Iвrahim et al., 2012a) the density of this species seems to be very low and consequently no important conclusions can be drawn on the phenology, abundance and contribution to the overall caddisfly community. In contrast to this, in Station 2 the population of $P$. rotundipennis seems to be stable and more abundant than in other localities. From this station it can be concluded that the flight period of this species starts in early September and continues up to the beginning of November. In the Netherlands it has been reported from August to October (Higler \& Solem, 1986) and in the United Kingdom it has been reported to emerge in spring and summer as well (CRICHTON, 1971). Previous caddisfly investigations in Station 2, where caddisflies were sampled during the spring period as well, did not reveal any specimen of $P$. rotundipennis (IвRAHimi et al., 2012a, 2015) which indicates that in the Balkans this species has an autumnal phenology.

$P$. rotundipennis is assessed as a rare and endangered species with fragmentary distribution in some parts of Europe. In Switzerland it has been classified as an endangered 
species according to the IUCN criteria because of its severely fragmented area and the continuing decline observed (LuBINI et al., 2012). In Hungary it was classified as presumed vulnerable at the end of the $20^{\text {th }}$ century with the remark that even though at present this species has a strong population in Hungary it may decline and shrink due to the degradation of its habitat (Nogradi \& Uherkovich, 1999). Another assessment of this species in Hungary a few years afterwards puts it in the list of vulnerable species (UHERKоvich \& Nogradi, 2005). In midwestern Poland out of 63 sampling sites, P. rotundipennis has been found in one site only (RYCHLA \& BUCZYNSKA, 2013). In Slovenia it is also a rare species (Urbanic, 2002). In Berlin and Brandenburg, Germany, it has been listed as an endangered species (Nev, 2013). Because of this and considering its severely fragmented distribution and the fact that at present it is known to exist at only four locations with considerable low abundance, Potamophylax rotundipennis should be treated as an endangered (EN) species among the caddisflies of Kosovo.

This investigation contributes to the better knowledge of the general distribution of this species in Europe and proves that the absence of data for this species from southeastern Europe is a result of a lack of investigation and its disjunct distribution, rather than a consequence of its absence. This investigation further highlights Blinajë Hungint Reserve as a refugium for several rare species in Kosovo and the Balkan Peninsula such as Mesophylax sperses (Iвraнim et al., 2015b), Tinodes jansenssi (the only record for Kosovo and one of few in the Balkans) (IвRAнiмi et al., 2012a) and the newly found Stenophylax permistus during this investigation. Rhyacophila fasciata is reported for the first time from Blinajë Hunting Reserve and is the only Rhyacophila- species found in this area.

Received June 22, 2016

\section{REFERENCES:}

Crichton, M.I., 1971: A study of caddisflies (Trichoptera) of the family Limnephilidae, based on the Rothamsted Insect Survey, 1964-68. Journal of Zoology (London) 163, 533-563.

Graf, W., Murphy, J., Dahl, J., Zamora-Muñoz C. \& López-Rodríguez, J. M., 2008: Trichoptera. In: Distribution and Ecological Preferences of European Freshwater Organisms. Series Ed. Schmidt-KLOIBER, A. \& Hering, D. 1, 1-388.

Higler, L. W. G. \& Solem, J. O., 1986: Key to the larvae of North-West European Potamophylax species (Trichoptera, Limnephilidae) with notes on their biology. Aquatic Insects: International Journal of Freshwater Entomology 8 (3), 159-169. doi: 10.1080/01650428609361247

Ibrahimi, H., Kučinić, M., Vitecek, S., Graf, W., Previšić, A., Bálint, M., Keresztes, L. \& Pauls, S.U., 2015a: New records for the Kosovo caddisfly fauna with description of a new species, Drusus dardanicus sp. nov. (Trichoptera: Limnephilidae). Zootaxa 4032, 551-568. doi: 10.11646/ zootaxa.4032.5.5

Ibrahimi, H., Previšić, A., Vitecek, S., Graf, W., Kučinić, M., Bálint, M., Keresztes, L. \& Pauls, S.U., 2016: Drusus sharrensis sp.n. (Trichoptera, Limnerphilidae) a new species from Sharr National Park in Kosovo with molecular and ecological notes. ZooKeys 559, 107-124. doi: 10.3897/zookeys.559.6350

IвrAhimi, H. \& Gashi A., 2008: State of knowledge of investigations on Trichoptera larvae in Kosova. Ferrantia 55, 70-73.

Ibrahimi, H., Gashi, A., Bilalli, A., Musliu, M., Grapci Kotori, L. \& Etemi-Zhushi, F., 2014a: Three new country records from the genus Limnephilus Leach, 1815 (Trichoptera: Limnephilidae) from the Republic of Kosovo. Biodiversity Data Journal 2, e4140. doi: 10.3897/BDJ.2.e4140

Ibrahimi, H., Gashi, A., Grapci-Kotori, L. \& Kučinić, M., 2013: First records of the genus Micropterna Stein, 1873 (Insecta: Trichoptera) in Kosovo with distributional and ecological notes. Natura Croatica 22 (1), 147-155.

Ibrahimi, H., Gashi, A., Grapci-Kotori, L., Bilalli, A., Musliu, M. \& Etemi-Zhushi, F., 2015b: First record of Mesophylax aspersus (Rambur, 1842) from the Republic of Kosovo (Trichoptera Limnephilidae). Biodiversity Journal 6 (1), 3-6. 
Ibrahimi, H., Kučinić, M., Gashi, A. \& Grapci Kotori, L., 2014b: Trichoptera Biodiversity of the Aegean and Adriatic Sea basins in Kosovo. Journal of Insect Science 14 (209), 1-8. doi: 10.1093/jisesa/ieu071

Ibrahimi, H., Kučinić, M., Gashi, A. \& Grapci Kotori, L., 2012a: The caddisfly fauna (Insecta, Trichoptera) of the rivers of the Black Sea basin in Kosovo with distributional data for some rare species. ZooKeys 182, 71-85. doi: 10.3897/zookeys.182.2485

Ibrahimi, H., Kučinić, M., Gashi, A., Grapci-Kotori, L., VučKović, I. \& CerJanec, D., 2012b: The genus Rhyacophila Pictet, 1873 (Insecta: Trichoptera) in Kosovo. Aquatic Insects: International Journal of Freshwater Entomology 34 (1), 23-31. doi: 10.1080/01650424.2012.643021

Illies, J. (ed.), 1978: Limnofauna Europaea. A Checklist of the Animals Inhabiting European Inland Waters, with an Account of their Distribution and Ecology. 2nd Edition. Gustav Fischer Verlag, Stuttgart. 552pp.

Kiss, O., Schmera, D. \& FeHER, I., 2003: Characteristics of caddis larvae assemblages from shallow lakes in the Bükk Mountains, North Hungary. Hydrobiologia 506-509, 365-372.

Kumanski, K. \& Malicky, H., 1999: A survey of the genus Potamophylax Wallengren 1891 in the Balkan Peninsula, with description of two new species (Trichoptera: Limnephilidae). Braueria 26, 27-30.

Kumanski, K., 1985: Trichoptera, Annulipalpia. Fauna Bulgarica 15. Bulgarska Akademi na Naukite, Sofia. 243 pp.

Kumanski, K., 1988: Trichoptera, Integripalpia. Fauna Bulgarica 19. -Bulgarska Akademi na Naukite, Sofia. 354 pp.

Lillehammer, A., 1978: The Trichoptera of Øvre Heimdalsvatn. Ecography 1(2-3), 255-260.

Lubini, V., Knispel, S., Sartori, M., Vicentini, H. \& Wagner, A., 2012: Listes rouges Ephémères, Plécoptères, Trichoptères. Espèces menacées en Suisse, état 2010. Office fédéral de l'environnement, Berne, et Centre Suisse de Cartographie de la Faune, Neuchâtel. L'environnement pratique $\mathrm{n}^{\circ} 1212$. 111 pp.

Malicky, H., 1986: Beschreibung von vier neuen KöcherfliegenArten aus der Turkei und aus Jugoslawien (Trichoptera). Opuscula Zoologica Fluminensia 4, 1-7.

Malicky, H., 1999: Bemerkungen uber die Verwandtschaft von Hydropsyche pellucidula Curtis (Trichoptera, Hydropsychidae). Linzer Biologische Beitraege 31 (2), 803-821.

Malicky, H., 2004: Atlas of European Trichoptera. 2nd Edition. Springer, Netherlands. 359 pp.

Marinković-Gospodnetić, M., 1975: Fauna Trichoptera SR Srbija. Zbornik radova o entomofauni Srbije 1, 219-236.

Marinković-Gospodnetić, M., 1980: Fauna Trichoptera SR Srbija. Zbornik radova o fauni Srbije 1, 71-84.

Neu, P., 2013: Checkliste der Köcherfliegen (Trichoptera) Deutschlands. http://www.trichoptera-rp.de/ Tricho-Liste_BRD__RL2013.pdf

Nogradi, S. \& Uherkovich, Ä., 1999: Protected and threatened caddisflies (Trichoptera) of Hungary. Proceedings of the 9th International Symposium on Trichoptera; Faculty of Science, University of Chiang Mai, Thailand, p. 291-297.

OlÁH, J., \& Kovács, T., 2013: New species and records of Balkan Trichoptera II. Folia Historico Naturalia Musei Matraensis 37, 109-121.

OLÁH, J., \& KovÁcs, T., 2014: New species and records of Balkan Trichoptera III. Folia Historico Naturalia Musei Matraensis 38, 97-131.

OlÁH, J., 2010: New species and new records of Palearctic Trichoptera in the material of the Hungary Natural History Museum. Annales Historico-Naturales Musei Nationalis Hungarici 102, 65-117.

Olá́, J., Ibrahimi, H. \& Kovács, T., 2013a: The genus Chaetopteroides (Trichoptera, Limnephilidae) revised by fine structure analysis of parameres. Folia Historico Naturalia Musei Matraensis 37, 93-108.

OláH, J., Lodovici, O., \& Valle, M., 2011: A new species of Potamophylax (Trichoptera, Limnephilidae) from Albania. Braueria 38, 13-14.

Oláh, J., Andersen, T., Chvojka, P., Coppa, G., Graf, W., Ibrahimi, H., Previšić, A. \& Valle, M., 2013b: The Potamophylax nigricornis group (Trichoptera, Limnephilidae): resolution of phylogenetic species by fine structure analysis. Opuscula Zoologica Budapest 44 (2), 167-200.

Pongrácz, S., 1923: Recésszárnyúak. Neuropteroiden. In: Csiki Erno Állattani Kutatásai Albániában. Explorationes zoologicae ab E. Csiki in Albania peractae. IX. A. Magyar Tudományos Akadémia Balkán-Kutatásainak Tudományos Erdményei 1, 160-166.

Radovanović, M., 1931: Rezultati ispitivanja balkanskih Trichoptera. Glasnik Jugoslovenskog entomološkog društva 1-2, 159-192. 
Rychla, A. \& Buczynska, E., 2013: Species richness and diversity of caddisflies (Trcihoptera) in a selected area in mid-western Poland (Lubuskie Province). Annales Universitatis Mariae Curie Sklodowska Lublin LXVIII (1), 55-73

Uherkovich, Ä. \& Nogradi, S., 2005: Caddisflies (Trichoptera) of the Mecsek Mts., a low, isolated mountain range in South Hungary. XVm. SIEEC, Linz. 37/1, 153-161.

Urbanič, G., 2002: The impact of the light tube and the distance of the light trap from a stream on a caddisfly. Natura Sloveniae 4 (1), 13-20.

Wallace, I., 2010: Scottish Invertebrate Species Knowledge Dossier: Trichoptera (Caddisflies). Butlife The Invertebrate Conservation Trust. 9 pp.

\title{
SUMMARY
}

\section{New data of Potamophylax rotundipennis (Brauer, 1857) and the first record of Stenophylax permistus McLachlan, 1895 (Trichoptera: Limnephilidae) from Kosovo}

\author{
H. Ibrahimi, V. Slavevska-Stamenković,' B. Rimcheska, A. Bilalli \& M. Musliu
}

Potamophylax rotundipennis is a widespread species in northwestern Europe but until recently there have been no reliable records from the Balkan Peninsula. In this paper we report two new occurrence localities of this species from the Balkan Peninsula, more precisely from the Republic of Kosovo, in addition to two localities, already reported a few years ago. The first sampling station is located around the spring area of the only stream in Blinajë Hunting Reserve in central Kosovo, and the second one is in the middle section of the Turuqicë tributary of the Llap River in northern Kosovo. Ecological notes of Potamophylax rotundipennis from both investigated localities are given. This investigation proves that the absence of data for this species from most of southeastern Europe is a result of the lack of investigations and its disjunct distribution, rather than a consequence of its absence. Considering its rare and fragmented distribution, Potamophylax rotundipennis should be treated as an endangered species among the caddisflies of Kosovo. In this paper we also report another limnephilid species, Stenophylax permistus, for the first time from the Republic of Kosovo. The species was also found in Blinajë Hunting Reserve. 